\title{
Physicochemical and Bacteriological Study of Sewage Before and After Treatment with Moringa Oleifera Seeds at Brazzaville (Congo)
}

\author{
Moyen Rachel $^{1,}$,, Serge Mdjouetede ${ }^{1}$, Nguimbi Etienne ${ }^{1}$, Baloki Ngoulou Tarcisse ${ }^{1}$, \\ Matini Laurent ${ }^{2}$ \\ ${ }^{1}$ Laboratory of Cellular and Molecular Biology, Sciences and Techniques Faculty, Marien Ngouabi University, Brazzaville, Congo \\ ${ }^{2}$ Laboratory of Applied Mineral Chemistry, Sciences and Techniques Faculty, Marien Ngouabi University, Brazzaville, Congo
}

\author{
Email address: \\ rmoyen@yahoo.fr (M. Rachel) \\ *Corresponding author
}

\section{To cite this article:}

Moyen Rachel, Serge Mdjouetede, NGUIMBI Etienne, Baloki Ngoulou Tarcisse, Matini Laurent. Physicochemical and Bacteriological Study of Sewage Before and After Treatment with Moringa Oleifera Seeds at Brazzaville (Congo). International Journal of Microbiology and Biotechnology. Vol. 6, No. 2, 2021, pp. 28-33. doi: 10.11648/j.ijmb.20210602.11

Received: March 3, 2021; Accepted: April 3, 2021; Published: April 13, 2021

\begin{abstract}
Within the framework of the mobilization of water resources and the supply of drinking water to the populations as well as the valuation of local materials, four (4) samples of piped water from the districts of Brazzaville were analyzed for their physical quality. chemical and microbiological before and after treatment with Moringa oleifera seed powder. The physicochemical parameters were determined using standard devices. As for the microbiological parameters, they were analyzed by conventional microbiological methods which consisted of isolation on selective media, identification using cultural, morphological and biochemical criteria and then counting. The results obtained concerning the physicochemical parameters showed that the raw water exhibited $\mathrm{pH}$ values ranging from 6.4 to 7.02 ; temperatures ranging from 25 to 25.8 with high values of turbidity and dry matter. However, low levels of magnesium and calcium ions have been noted. Regarding the microbiological parameters, this water exhibited bacteria of the genus Staphylococcus as well as fecal and total coliforms, a large number of which were unidentified. The genera Salmonella and Shigella have been identified as well as the species E. coli, an indicator of contamination. After clarification of the Moringa beans with powder, the $\mathrm{pH}$ values varied from 5.40 to 4.02; there is a decrease in turbidity as well as the dry matter. Microbiologically, the clarified water contained unidentified coliforms with persistence of Salmonella and Staphylococci in low proportions. As for E coli and Shigella, they have been totally eliminated. After clarification and decantation, the results show that all the microorganisms are found concentrated in the sludge. Before treatment, the cloudy pipe water exhibited high concentrations of organic and mineral chemicals. These analyzed waters contained several types of germs in very high numbers. The muddy water is decanted, clarified and purified by the powder of Moringa oleifera seeds in less than 2 hours. However, there is a decrease in the number of germs in the clarified water with the formation of an activated sludge. Moringa oléifera is therefore a local plant material that can be used in the treatment of wastewater to prevent possible contamination.
\end{abstract}

Keywords: Muddy Water, Pipeline, Quality, Treatment, Moringa Oléifera

\section{Introduction}

Water is a commodity that conditions people's lives at all times and in all places. The survival of mankind therefore depends on the ability to share and manage this vital resource. In arid and semi-arid zones, this vital and symbolic resource profoundly conditions societies. This is why, in these areas, there is often recourse to groundwater resources, which are true secret reserves, long unknown [1]. According to UNESCO, the world's population has grown from 3 billion to 6.8 billion people, resulting in a growing need for drinking water. However, an estimated 1.3 billion people do not have access to safe drinking water, the majority of whom are in Africa [2]. Every year, approximately 1.5 million children die 
from water-borne diseases. The degradation of water quality in rivers, lakes and groundwater has a direct impact on ecosystems and human health. Such a situation represents a terrible human tragedy and a major obstacle to development [2]. Moringa oleifera is a plant that grows in all regions of the world. It abounds in several virtues: medicinal, physiological, biochemical etc... All these virtues are related to the chemical composition of the plant in general and in particular to that of its seeds. Indeed, Moringa oleifera seeds contain lipids, carbohydrates and mucilaginous proteins [3]. Thus, we want to take advantage of the virtues of Moringa oleifera, an available natural resource, in order to reduce the dependence on expensive chemical products and to bring a solution in the treatment of sewage water for a possible redistribution.

\section{Materials and Methods}

\subsection{Material}

The study material has been constituted:

Samples of sewage water from four (4) districts of Brazzaville: La Glacière, (Bacongo), Diata (Makelekele), Plateau des 15 ans and Moungali center (Moungali).

The powder of oven-dried Moringa oleifera seeds. The seeds are crushed in a mortar and then finely ground using a Moulinex grinder. The following culture media were used for the isolation of microorganisms before and after clarification of the different water samples: EMB Agar, Mac conkey Agar, Chapman Agar, SS Agar.

\subsection{Methods}

\subsubsection{Physiochemical Study}

The different parameters were analyzed before water treatment and after water treatment with Moringa powder.

\section{(i). pH, Temperature and Electrical Conductivity}

These parameters were measured using the electrochemical method with a pre-calibrated multifunction $\mathrm{pH}$ meter. The two electrodes of the instrument are directly immersed in the sample to be analyzed. The $\mathrm{pH}$ of the solution, the temperature (in ${ }^{\circ} \mathrm{C}$ ) and the electrical conductivity (in $\mu \mathrm{s} / \mathrm{cm}$ ) are automatically displayed on the instrument's screen.

\section{(ii). Turbidity}

It was determined by measuring the absorbance with a spectrophotometer at a wavelength of $520 \mathrm{~nm}$ using an apparatus (REf apparatus). It is expressed in Formazine Unit (FTU). These units are practically equivalent to Jackson units (JTU) and nephelometric units (NTU). The turbidity value expressed in FTU is read directly from the display [4].

\section{(iii). Calcium}

The test is used to determine the hardness of the water and is called the Calcium Hardness Test or Palin Test. It is based on the Calcicol Indicator Reagent method. Calcium ions react especially with the Calcicol indicator in an alkaline solution to give an orange coloration. The reagent itself gives a purple color in the presence of an alkaline solution. After sample preparation and staining, the reading is taken with the spectrophotometer at $570 \mathrm{~nm} \mathrm{[4].}$

\section{(iv). Magnesium}

Magnesium gives an orange coloration in the presence of a naturally yellow reagent in solution. The color developed is proportional to the magnesium concentration of the sample to be analyzed. The magnesium is measured at $520 \mathrm{~nm}$ on the photometer using the Wavelength bar. To determine the magnesium hardness in $\mathrm{mg} / \mathrm{L} \mathrm{CaCO} 3$ multiply by 4.2 [4].

\section{(v). Suspended Matter}

TSS are defined as the residues retained on a filter membrane of $0.45 \mu \mathrm{m}$ nominal porosity after drying at $105^{\circ} \mathrm{C}$. The presence of TSS causes turbidity in the water and can affect the growth of various living organisms. A $100 \mathrm{~mL}$ water sample is filtered through a filter membrane with a nominal porosity of $0.45 \mu \mathrm{m}$, previously rinsed and dried at $105^{\circ} \mathrm{C}$. The material retained on the filter is dried at $105^{\circ} \mathrm{C}$ and weighed with the filter. The mass of TSS is obtained by differentiating the mass of the filter including the dried residue from the initial mass of the filter, taking into account the filtered volume [4].

\subsubsection{Microbiological Analysis}

The study was done with untreated water samples and samples treated with $100 \mathrm{~g}$ of Moringa oleifera powder. The inoculum consisted of $10 \mathrm{~mL}$ of the different raw water samples, $10 \mathrm{~mL}$ of the supernatant collected after treatment for each sample and then the settling sludge.

\section{(i). Isolation}

$2 \mu \mathrm{l}$ of these samples were inoculated on Petri dishes containing selective and non-selective culture media, and incubated in an oven at $37^{\circ} \mathrm{C}$ for 18 to 24 . The following media were used:

Mac Conkey Agar medium, an isolation medium for Enterobacteriaceae;

Chapman Agar medium, a selective medium for bacteria of the genus Staphylococcus

EMB Agar medium is used to isolate and identify Escherichia coli and Enterobacter as well as gram-negative intestinal bacteria;

SS Agar medium is a selective and differential medium for the isolation of pathogenic enteric bacilli belonging to the genera Salmonella and Shigella.

\section{(ii). Identification}

It was made from the cultural, morphological and biochemical characteristics. The morphological characteristics were determined by microscopic examination of the colonies observed in the fresh state and after staining, and the morphological characteristics were determined by microscopic examination of the colonies observed in the fresh state and after staining. Biochemical characteristics were determined from the metabolic reactions of the different colonies. The production of certain enzymes such as catalase, coagulase, sugar fermentation was studied. 


\section{(iii). Enumeration of Bacteria in Liquid Medium}

It was carried out by the method of dilution in liquid medium then seeding on solid medium. The bacteria present in the inoculum are enumerated on the surface of an agar medium. Each isolated bacterium gives rise to a colony or CFU for "Colony Format Unit". Three boxes are inoculated by dilution. Petri dishes are incubated at $37^{\circ}-45^{\circ} \mathrm{C}$ for $24-48$ hours. The NPP method, derived from Mac Crady's studies, consists of interpreting the results by comparing the three test tubes and their results [5]. After incubation, record for each test tube whether the result is positive or negative. For each test tube, assign a number equal to the sum of the positive tubes Table 1.

\section{Results}

\subsection{Raw Water}

\subsubsection{Physico-chemical Parameters}

The values of the different parameters measured are presented in the table below. According to the results of the physico-chemical parameters of the raw water in Table 2, the and $25.8^{\circ} \mathrm{C}$, the E. C. between 100.8 and $1562 \mu \mathrm{S} / \mathrm{cm}$. The
$\mathrm{Ca}^{2+}$ and $\mathrm{Mg}^{2+}$ concentrations vary between 7 and $12 \mathrm{mg} / \mathrm{L}, 1$ and $10 \mathrm{mg} / \mathrm{L}$ respectively. Turbidity is less than 5 FTU and TSS are between 4.03 and $4.99 \mathrm{mg} / \mathrm{L}$.

\subsubsection{Bacteriological ANALYSIS}

The culture media used allowed us to highlight all families of Enterobacteriaceae, specifically E.coli, Salmonella spp, Shigella spp and Staphyloccoccus. Table 3 gives us the quantities of germs contained in the muddy water in the pipes.

\subsection{Water Clarified with Moringa Oleifera Seed Powder}

\subsubsection{Physico-chemical Parameters}

The values of the different physicochemical parameters measured are recorded in Table 4.

\subsubsection{Bacteriological Analysis}

The results of the bacteriological analysis are shown in Table 5.

\subsection{Activated Mud}

Microbiological analyses performed on the activated sludge yielded the following results Table 6 .

Table 1. Example: With three dilution tubes.

\begin{tabular}{|c|c|c|c|c|c|c|c|c|c|c|c|c|}
\hline Dilution & $10^{0}$ & & & 10 & & & $10^{-2}$ & & & 10 & & \\
\hline Results & + & + & + & + & + & - & + & - & - & - & - & - \\
\hline Figures attributed to each positive dilution & 3 & & & 2 & & & 1 & & & 0 & & \\
\hline
\end{tabular}

Table 2. Values of measured physico-chemical parameters.

\begin{tabular}{|c|c|c|c|c|c|c|c|}
\hline \multirow{2}{*}{ Samples } & \multirow{2}{*}{ pH } & \multirow{2}{*}{$\mathbf{T}\left({ }^{\circ} \mathbf{C}\right)$} & C. $\mathbf{E}$ & TURB & $\mathrm{Ca}^{2+}$ & $\mathrm{Mg}^{2+}$ & MES \\
\hline & & & $\mu \mathrm{S} / \mathrm{cm}$ & FTU & $\mathrm{mg} / \mathrm{L}$ & $\mathrm{mg} / \mathrm{L}$ & $\mathrm{mg} / \mathrm{L}$ \\
\hline 1 & 6,4 & 25,7 & 1562 & $<5$ & 7 & 10 & 4,14 \\
\hline 2 & 6,65 & 25,8 & 100,8 & $<5$ & 12 & 6 & 4,99 \\
\hline 3 & 6,36 & 25,8 & 910 & $<5$ & 8 & 1 & 4,62 \\
\hline 4 & 7,02 & 25,8 & 1017 & $<5$ & 10 & 4 & 4,03 \\
\hline WHO standards & $6,5-9,00$ & $12-30^{\circ} \mathrm{C}$ & & 5 & 70 & 50 & $<1$ \\
\hline
\end{tabular}

pH: Hydrogen potential, $\mathrm{T}\left({ }^{\circ} \mathrm{C}\right)$ : Temperature in degrees Celsius, C. E: Electrical conductivity; TURB: Turbidity; Ca2+: Calcium ion, Mg2+: Magnesium ion, MES: Suspended matter.

Table 3. Quantity of bacteria.

\begin{tabular}{|c|c|c|c|c|c|}
\hline Samples & Other unidentified coliforms & E.coli & Salmonella spp & Shigella spp & Staphylococcus \\
\hline 1 & $3.875 .10^{5}$ & - & $15.10^{4}$ & $125.10^{3}$ & $205.10^{6}$ \\
\hline 2 & $62.375 .10^{4}$ & $21.10^{4}$ & - & $14.10^{4}$ & $28.125 .10^{4}$ \\
\hline 3 & $5.125 .10^{5}$ & $135.10^{3}$ & $12.10^{4}$ & $13.10^{4}$ & $1.875 .10^{5}$ \\
\hline 4 & $6.125 .10^{5}$ & - & - & $11.10^{4}$ & $28.875 .10^{4}$ \\
\hline
\end{tabular}

pH: Hydrogen potential, T $\left({ }^{\circ} \mathrm{C}\right)$ : Temperature in degrees Celsius, C. E: Electrical conductivity; TURB: Turbidity; Ca2+: Calcium ion, Mg2+: Magnesium ion, TSS: Suspended solids.

Table 4. Values of the physico-chemical parameters.

\begin{tabular}{|c|c|c|c|c|c|c|c|}
\hline Samples & pH & $\mathbf{T}^{\circ} \mathbf{C}$ & C. $E \mu S / c m$ & TURB FTU & $\mathrm{Ca}^{2+} \mathrm{mg} / \mathrm{L}$ & $\mathrm{Mg}^{2+} \mathrm{mg} / \mathrm{L}$ & MES mg/L \\
\hline 1 & 5,40 & 25,7 & 119,9 & $<5$ & 6 & 4 & 1,06 \\
\hline 2 & 4,72 & 25,8 & 2,30 & $<5$ & 11 & 7 & 1,08 \\
\hline 3 & 5,40 & 25,8 & 121,2 & $<5$ & 3 & 1 & 1,04 \\
\hline 4 & 4,05 & 25,8 & 156,7 & $<5$ & 9 & 3 & 1,07 \\
\hline
\end{tabular}

pH: Hydrogen potential, T $\left({ }^{\circ} \mathrm{C}\right)$ : Temperature in degrees Celsius, C. E: Electrical conductivity; TURB: Turbidity; Ca2+: Calcium ion, Mg2+: Magnesium ion, TSS: Suspended solids. 
Table 5. Values of bacteriological parameters.

\begin{tabular}{llllll}
\hline Samples & Other unidentified coliforms & E.coli & Salmonella spp & Shigella spp & Staphylococcus \\
\hline 1 & $205.10^{6}$ & - & $11.10^{4}$ & - & $19.10^{7}$ \\
2 & $24.375 .10^{4}$ & - & - & - & - \\
3 & $2.625 .10^{5}$ & - & - & - & - \\
4 & $3.125 .10^{5}$ & - & - & - & - \\
\hline
\end{tabular}

Table 6. Quantity of germs isolated.

\begin{tabular}{llllll}
\hline Samples & Other unidentified coliforms & E.coli & Salmonella spp & Shigella spp & Staphylococcus \\
\hline 1 & $325.10^{6}$ & - & $115.10^{3}$ & - & $175.10^{6}$ \\
2 & $30.625 .10^{4}$ & $15.10^{4}$ & - & $11.10^{4}$ & $1.625 .10^{6}$ \\
3 & $2.875 .10^{5}$ & $105.10^{3}$ & - & $115.10^{3}$ & $16.10^{7}$ \\
4 & $35.10^{5}$ & - & - & $105.10^{3}$ & $185.10^{6}$ \\
\hline
\end{tabular}

\section{Discussion}

\subsection{Physico-chemical Parameters}

The main parameters of interest in the proper functioning of a biological treatment plant, carried out in our study are: $\mathrm{pH}$, temperature, turbidity, electrical conductivity, TSS, calcium and magnesium. Temperature and $\mathrm{pH}$ influence the multiplication of bacteria. An excess of TSS can cause clogging of the pre-treatment system. Also, waste water with too much organic matter will be incompletely treated, as it requires more intense microbial activity.

From our results, it appears that the values of $\mathrm{pH}$, temperature, electrical conductivity, turbidity, calcium, magnesium and suspended solids are respectively between 4.05 and $7.02 ; 25.7^{\circ}$ and $25.8^{\circ} \mathrm{C} ; 2.30$ and $156.7 \mu \mathrm{S} / \mathrm{cm}$; less than $5 ; 3$ and $12 \mathrm{mg} / \mathrm{L} ; 1$ and $10 \mathrm{mg} / \mathrm{L}$ and 1.04 and $4.99 \mathrm{mg} / \mathrm{L}$. The $\mathrm{pH}$ values of the raw water do not fully meet the WHO standards for wastewater discharge, which recommend a $\mathrm{pH}$ between $6.5-9.00$, however the $\mathrm{pH}$ of the water treated with Moringa oleifera seed is below the standards.

Our raw water $\mathrm{pH}$ results (6.36 to 7.02) differ from those found by Makhoukh $\mathrm{M}$ and al. [6] in Eastern Morocco $\mathrm{pH}=7.04$ to 7.89 , by Abouelouafa and al. [7], in Morocco $\mathrm{pH}=5.4$ to 8.05 , by Guamri and al. [8], $\mathrm{pH}=7.2$ in Morocco, by Belghyti and al [9] in Rabat $\mathrm{pH}=7.5$ by Nola et al.[10]; $\mathrm{pH}=7.24$, by Balok et al.[11] 8.47 to 9.49 and by Pkia Eddabra [12] $\mathrm{pH}=7.71$.

Our temperature values range from $25.7^{\circ} \mathrm{C}$ to $25.8^{\circ} \mathrm{C}$. These results disagree with those found by Makhoukh $\mathrm{M}$ and al [6] in eastern Morocco in the study of surface water in the dry season, by Guamri and al. also by Belghyti and al $[8,9]$ in Rabat, by Abouelouafa and al, Pkia Eddabra, Parihar [7, 12, 13] and Baloki and al. [11] on household wastewater, whose respective averages are: $29^{\circ} \mathrm{C}, 20.8^{\circ} \mathrm{C}, 21,5^{\circ} \mathrm{C} ; 21.11$ to $22.95^{\circ} \mathrm{C} ; 17$ to $29^{\circ} \mathrm{C} ; 28$ to $31^{\circ} \mathrm{C}$ and 22.03 to $23.55^{\circ} \mathrm{C}$.

From our study, it appears that the average electrical conductivity of the raw water ranges from 910 to $1562 \mu \mathrm{s} / \mathrm{cm}$. Our results differ from those found by Amghar et al. [16] in Ghana E. C. $=4520 \mu \mathrm{s} / \mathrm{cm},[10]$, E. C. $=6320 \mu \mathrm{s} / \mathrm{cm}$. For some sites, they are close to those found by Pkia Eddabra [13] in India, where the respective averages range from 1510 to 3660 $\mu \mathrm{s} / \mathrm{cm}$ and Baloki [11] in Congo Brazzaville 518.37 to
$2660.11 \mu \mathrm{s} / \mathrm{cm}$ and quite close to those found by Mukhopadhyayet al., and by Ouali et al $[14,15]$ in Morocco, whose averages are: 1230 to $1466.68 \mu \mathrm{s} / \mathrm{cm} ; 1360.5 \mu \mathrm{s} / \mathrm{cm}$. In comparison with the USAID standard, these waters should be used with caution since the electrical conductivity is less than $3000 \mathrm{mg} / \mathrm{L}$. The average values recorded do not exceed the Moroccan standard for surface water $(2700 \mu \mathrm{s} / \mathrm{cm})$. Our results could can be explained on the one hand by the presence of several dissolved solids (strong mineralization) and on the other hand by a continuous supply of household waste.

The average turbidity is less than 5 NTU. Our results are similar to those found by Mukhopadhyayet al. and by Srivastava et al. $[14,17]$ whose averages range from 1.5 to 3.5 NTU, from 0.3 to 1 NTU. This differs from those found by Baloki et al. and by Attab $[18,11]$ whose means range from 161 to 453 NTU and 100 to 482 NTU. The lowest turbidity value is. The turbidity values can be explained by the high content of colloidal material of mineral or organic origin (sands, microorganisms.). The values for temperature, turbidity, calcium and magnesium are in accordance with the WHO standards for wastewater discharges which recommend respectively between $12-30^{\circ} \mathrm{C} ; 5 ; 70 \mathrm{mg} / \mathrm{L}$ and $50 \mathrm{mg} / \mathrm{L}$.

As for the suspended matter, the results of our work give values higher than those recommended by the WHO standards [21].

The Suspension matter of the measured raw waters vary from 4.03 to 4.99 . Our results are different from those reported by Niang Sophie [19]. for the waste water of Dakar at Senegal. And those reported by Makhoukh and al. and also Belghyti and al. in Rabat $[6,9]$. whose values vary between 33 and 651 $\mathrm{mg} / \mathrm{L} ; 123 \mathrm{mg} / \mathrm{L}$ (S1) and $2730 \mathrm{mg} / \mathrm{L}(\mathrm{S} 2) ; 513 \mathrm{mg} / \mathrm{L}$ and 482 $\mathrm{mg} / \mathrm{L}$ and $122 \mathrm{mg} / \mathrm{L}$ to $1067.25 \mathrm{mg} / \mathrm{L}$ [11]. These results can be explained by the presence of poorly biodegradable materials and/or by a continuous supply of household waste [20].

Studies in Thyolo, southern Malawi, have shown that the turbidity of impure water (turbidity of 1000 FTU) could be reduced to less than 10 FTU by coagulation/sedimentation. The same experiment carried out with sand filters gave a final turbidity of 1 FTU. A filtration using the sand gravity technique finally gave a water turbidity generally below 5 MPO [21]. The temperature, suspended solids and $\mathrm{pH}$ values obtained in our work are lower than those reported by Yao Akpo [22] which are $29.2^{\circ} \mathrm{C}$ for temperature, $699 \mathrm{mg} / \mathrm{L}$ for 
suspended solids and 7.7 for $\mathrm{pH}$. The average TSS values recorded in the water clarified with Moringa oleifera make it possible to assess the purifying performance of this plant.

\subsection{Bacteriological Parameters}

The raw muddy waters analyzed are highly loaded with Enterobacteriaceae and Staphylococci with the presence of E. coli, Salmonella spp and Shigella spp depending on the samples. This bacterial load is much higher than that reported by Aboulkacem and al. [23] which is 107 to $109 \mathrm{CF} / 100 \mathrm{~mL}$. However, a decrease or total disappearance of the bacterial load in the clarified water can be observed depending on the samples and the amount of Moringa oleifera incubated. This bacterial load, which settles, becomes more abundant in the sludge. These results clearly show the purifying performances of Moringa oleifera. The purifying performances of the Moringa oleifera seed powder according to its concentration are demonstrated in the sample where unidentified coliforms, Salmonella spp, Shigella spp and Staphylococci are observed at high levels. Clarification with $25 \mathrm{~g}$ of powder led to a decrease of the entire load. However, with $50 \mathrm{~g}$ of powder a total disappearance of Shigella spp. is observed, so this concentration is bactericidal for Shigella.

In the raw water of sample number 2 we note the presence of unidentified Enterobacteriaceae, E.coli, Shigella spp and Staphylococcus, after treatment with Moringa oleifera seed powder dosed at $50 \mathrm{~g}$ we notice the decrease of Enterobacteriaceae numbers and the elimination of E.coli, Shigella spp and Staphylococcus. The same results were observed for samples number 3 and 4 treated with the seed powder at doses of $75 \mathrm{~g}$ and $100 \mathrm{~g}$ respectively with elimination of Salmonella spp. These results show that the coliform load of the treated water is higher than the WHO standards for wastewater discharge into the natural environment, which is $1000 \mathrm{CFU} / 100 \mathrm{~mL}$. According to the $\mathrm{WHO}$, the presence of $\mathrm{E}$. coli in these waters is an indicator of fecal pollution. Studies conducted in Thyolo, southern Malawi [24], at a river water treatment plant that is pumped $24 \mathrm{~m}^{3} /$ day to an upper tank/mixer where shelled Moringa oleifera seeds are dosed at $200 \mathrm{mg}$ per liter, showed that coliforms were reduced to $96 \%$. These results are related to the properties of the Moringa oleifera seed powder.

\section{Conclusion}

The results of our study show that sewage water contains both chemical and microbiological pollutants at high concentrations. The use of Moringa oleifera seed powder at different concentrations not only clarifies the muddy water in less than 2 hours, but also shows the decantation of biological pollutants; this explains the purifying power of Moringa oleifera seed powder by taking advantage of its bacteriostatic and bactericidal activities. These properties of Moringa oleifera seeds can be exploited in arid countries on a large scale as part of the mobilization of drinking water resources in place of chemical coagulants and flocculants.

\section{References}

[1] Barhoumi-Andréani Y. (2004). Eau: Ressources et Menaces, Water: Resources and Threats 47p. https://www.etudier.com/dissertations/Eau-Ressources-Et-Me naces/46418124.html.

[2] Pene P. et Levi Y. (2011). Les eaux de consommation humaine et la santé publique en France métropolitaine. Bulletin de l'Académie Nationale de Médecine. 195, 403-429.

[3] Gauthier F. (2002). Biofilms et qualité biologique de l'eau potable au cours de sa distribution; Mémoire de DESS de l'Université de Picardie Amiens, 78p.

[4] AFNOR, (1997). Water quality. Compilation of French Environmental Standards. Volumes 1, 2, 3 and 4. 1372 p.

[5] Manuel pratique d'analyse de l'eau, 2013, Fondation Nationale de la Santé Bresilia $4^{\mathrm{e}}$ Edition, P 21-24/153p. http://www.funasa.gov.br/site/wp.

[6] Makhoukh M., M. Sba1, A. Berrahou, M. Van. Clooster. (2011) Contribution to the physico-chemical study of the surface waters of the moulouyawadi (Eastern Morocco) Larhyss Journal, ISSN 1112-3680, $\mathrm{n}^{\circ}$ 09: 150-169.

[7] Abouelouafa Mounia, El Halouani Hassan, Kharboua Mohammed \& Berrichi Abdel bass. (2002). Physical, chemical and bacteriological characterization of raw wastewater in the city of Oujda: main canal and Oued Bounaïm. Inst. Acts Agron. Vet. (Morocco). Vol. 22, (3) 143-150.

[8] Guamri Y. El, D. Belghyti, M. Cisse, K. El Kharrim, I. Sylla, S. Raweh, H. Barkia, T. Hassouni and A. Jamber. (2007). Physico-chemical and parasitological study of wastewater intended for irrigation of the peri-urban perimeter of Fouarat (Kenitra, Morocco). African Agronomy. 19 (3): 251-261.

[9] Belghyti Driss, Youssef El Guamri, Ghizlane Ztit, My. Lahcen Ouahidi, My Brahim Joti, Abdelatif Harchrass et al (2009). Physico-chemical characterisation of slaughterhouse waste water with a view to implementing appropriate treatment: case of Kenitra in Morocco. Africa science. 05 (2) 153-216.

[10] Nola M., T. Njiné, N. Kemka, S. H. Zébazé Togouet, P. Servais, M. Messouli et al. (2006). Transfer of faecal bacteria to a water table through a soil column in the equatorial region: Influence of the water load applied to the surface. Revue des sciences de l'eau. vol. 19, no 2. 101-112.

[11] Baloki Ngoulou Tarcisse, Moyen Rachel, Nguimbi Etienne, Ahombo Gabriel, Matini Laurent. (2019). Study of the Physico-Chemical and Microbiological Parameters of Household Wastewater in Brazzaville. International Journal of Environmental Science. ISSN: 2367-8941; Vol 4: 80 - 90. http://www.iaras.org/iaras/journals/ijes.

[12] Pkia Eddabra. (2011). Evaluation of bacteriological contamination of wastewater from wastewater treatment plants of the large AGADIR: Isolation, molecular characterization and antibiotic resistance of vibrio species. Thesis. 1-146.

[13] Parihar S. S., Kumar Ajit, Kumar Ajay, Gupta R. N., Pathak Manoj, Shrivastav Archana and Pandey A. C. (2012). Physico-Chemical and Microbiological Analysis of Underground Water in and Around Gwalior City, MP, India Research Journal of Recent Sciences. ISSN 2277-2502. Vol. 1 (6): 62-65. 
[14] Mukhopadhyay Sabyasachi, Ratul Mukherjee. (2013). Physico - Chemical and microbiological quality assessment of groundwater in adjoining area of Tamla Nala, Durgapur, District: Burdwan (W. B.), India. Environmental sciences issn 0976 - 4402 Volume 4, No 3: 360-366.

[15] Ouali El Lalami A., Merzouki M., El Hillali O., Maniar S., IbnsoudaKoraichi S. (2010). Pollution of surface water in the City of FES in Morocco: typology, origin and consequences. Larhyss journal, ISSN 1112-3680, $\mathrm{n}^{\circ}$ 09: 55-72.

[16] Amghar H. (2002). Assessment of the impact of metal pollution on the waters of Lake Fouarat (Gharb region). Postgraduate thesis, Fac. Sci., Kenitra, 1-113. Available at www.ebanque-pdf.com/fr_water-metallic-pollution.html.

[17] Srivastava Kumar Ratna and Deepti Pandey. (2013). Physico -chemical and microbiological quality evaluation of groundwater for human domestic consumption in adjoining area of OmtiNallah, Jabalpur (M. P.), India Environmental Sciences ISSN 0976 - 4402. Vol 3, No 4: 1300-1307.

[18] Attab Sarah. (2011). Improvement of the microbiological quality of the water treated with activated sludge from the Haoud Berkaoui wastewater treatment plant by using a local sand filter. Magister in Algeria. 1-152p.

[19] Niang Sophie. (1998). Purification of urban wastewater by reconstituted hydrosers. Experimental research on a technology appropriate for West Africa. Reports which. Were presented for the Cities Feeding People workshop: "Lessons learned from urban agriculture projects in African cities" Nairobi, Kenya, $1-67$.

[20] Fathallah Z., Elkharrim K., Fathallah R., Hbaiz E M., Hamid C., Ayyach A., Elkhadmaoui A., Belghyti D. (2014). Physico-chemical study of waste water from the paper industry unit (cdm) at Sidi Yahia El Gharb (Morocco).

[21] Ayress. R. M. 1997, Analyse des eaux résiduaires en vue de leur recyclage en agriculture. Manuel de techniques de laboratoire en parasitologie et bactériologie Genève: OMS, P 30 .

[22] Yao Akpo, 2006, Evaluation de la pollution des eaux usées domestiques collectées et traitées à la station d'épuration de Camberène (Dakar), Mémoire de D. E. A, Université Cheick Anta Diop, P 31.

[23] Aboulkacem A., A. Chahlaoui, A. Soulaymani, F. Rhazi-Filaliet D. Benali. (2007). Bacteriological comparative study of the waters of the Boufekrane and Ouislanewadis crossing the city of Meknes (Morocco). Discount, Vol. 1, No. 1. $10-22$.

[24] Folkard. G, J. Sutherland et R. Shaw. R, (1999). Water Clarification using Moringa oleifera. Technical Information W1e. P. 1-7. 